\title{
拡散対の濃度均一化過程に生ずる 多相拡散の数值解析
}

\author{
过新次頃安貞利
}

帝京大学理工学部機械・精密システム工学科

J. Japan Inst. Metals, Vol. 61, No. 1 (1997), pp. 8-17

\section{Numerical Analysis of Multiphase Diffusion in Homogenization Process of Diffusion Couples}

\author{
Shinji Tsuji and Sadatoshi Koroyasu \\ Department of Mechanical and Precision System, School of Science and Engineering, Teikyo University, \\ Utsunomiya, Tochigi 320
}

\begin{abstract}
A general model to treat multiphase diffusions in a semi-infinite couple after impregnation, a finite/semi-infinite couple and a finite/finite couple is presented on the finite difference solutions with a variable-grid. In the model, the numerical solutions previously presented for the multiphase diffusions in a semi-infinite medium whose surface is maintained at a constant concentration, and an infinite medium are used as a means of giving the initial conditions, respectively.

Critical layer widths for the occurrence of a new phase and for the disappearance of a preexisting phase, and critical values defining whether to calculate the change in concentration for a terminal phase are introduced in this model in order to diminish the number of iterations in the calculation and successfully to apply its model to a great variety of binary alloys.

The resultant surface concentrations and layer widths of existing phases at any time, for example, may be given as part of data which have been stored in the form of concentration profiles as a function of diffusion time. Typical examples to which the model has been applied are discussed.
\end{abstract}

(Received September 5, 1996) Keywords: binary alloy, impregnated semi-infinite couple, finite/semi-infinite couple, finite/finite
couple, homogenization, multiphase diffusion, finite difference method

\section{I. 緒言}

拡散領域内に異相界面や，金属間化合物などの中間相が形 成される相互拡散現象は，一般に，多相拡散古るいは反応桩 散と呼ばれている。著者は無限体执よび半無限体に和ける2 元系多相拡散を 2 変数問題として取り扱い, これらの解を 数值的に求める方法を既に明らかにした(1)(2).

一方, 浸透処理後拡散処理を行った半無限拡散対, 有限厚 さの薄板よりなる有限/有限抎散対, お上び有限/半無限拡散 対などに括ける多相拡散は，それぞれ，A1 浸透処理後の組 成調整法として ${ }^{(3)}$ ，金属間化合物の新しい製法の一つとし $て^{(4)(5)}$, シリコンウェハとスパッタされた金属薄膜間に拈け るシリサイド形成 (6) (7)や加熱によるめっき皮膜と素地との相 互拡散による新相の形成 ${ }^{(8)}{ }^{(9)}$ といった害用的観点からも注目 を浴びている、しかしここれらの多相拡散においては拡散の 進行とともに表面濃度が減少する結果，表面に近い相の消失 が起こりそれに前後して内側の相の層幅が増加から減少に軽
じるなどの複雑な過程を伴って, 拡散対内に打ける濃度の均 一化に向けて拡散が進行する。このよ5な扗散現象に対して はボルッマン変数の導入が不可能であり, もはや解析的に解 くことは不可能となる。

相消失を伴い, 組成の均一化に向かって進行する 2 元系 多相拡散に関して，既に Heckel ら (3)(10)-(12)が，また最近 下嵉ら(13)(14) が差分法を用いた数值解析法を明らかにしてい る.このような問題に対して差分法に基づく数值計算を行う 場合, 各相での濃度-距離曲線が初期值として与兄られてい ることが必要である. Hick1 らは半無限体に乱沙る多相拡散 の解析解を初期值として用いているが，彼らの方法(3)(11)で は, 解析解は 3 相までが限度であり，4相以上の一般的な解 は与えられていない，一方下暗らは，初期值を試行錯誤法で 求めることによって，この問題を解決している(13). しかし， 格子点を拡散領域全般にわたって等間隔に定めているので, 層厚さが相によって極端に異なる場合, 距離行分割数が多く なるため計算時間が著しく長くなり，また異相界面が格子点 に必ずしも位置しないため，取扱いが煩雑となる。 
本研究の目的は，蔇に明らか炕した 2 元系多相拡散に関 する数値解析解(1)(2) から計算した濃度-距離曲線を初期值と して与克, 相の消失を伴い, 濃度の均一化に向かって進行卞 る多相桩散をシミュレートする数値計算法を明らかにするこ とにある。な扣本研究に打いては，浸透処理後均一化桩散娃 理を行ら半無限型拡散試料, 有限/有限拡散対扣よび有限/半 無限拉散対に和ける多相拡散を解析の対象としている。

本方法によって得た数值計算結果を他の研究者らによって 得られた実験結果と比較検討するとともに，計算精度执よび 計算時間の各種計算条件への依存性を明らか炕するの子本研 究の目的の一つである。

\section{II. 数 值 解 析}

\section{1. 初期值}

本研究に扔いては下記の仮定に基ついて数值解析を行った。

（1）異相界面は一稼な平面を形成する.

（2）異相界面に打ける境界組成は拡散時間に依存しない。

（3）各相の相互拡散係数は組成に依存しない.

（4）拡散成分の部分モル体積は系のあらゆる組成に関して 一定である。

有限/半無限拡散対は，濃度 $C_{-}$和よび厚さ $\left(-L_{-}\right)$を有す る有限体と，濃度 $C_{+}$物よび厚さ $L_{+}$省有する半無限体から 構成されるものと考光る。この型の拡散対に関して，任意の 拡散時間，すなわら差分法での任意の時刻行 i 亿扣ける濃度一 距離曲線を模式的に Fig. 1 に示す，距離刻み幅としては， 相による層幅の違いを無視して，すべての相に関して層幅を ある整数值で除した值を用いた．したがって，各相の距離刻 み幅は，拡散時間ととるに変動する値をとることになる。す なわち，時刻行ｉに打る相：距離刻又幅を

$$
\Delta \mathrm{x}_{\mathrm{j}}^{\mathrm{i}}=\frac{X_{\mathrm{j}, \mathrm{m}}^{\mathrm{i}}-X_{\mathrm{j}, 0}^{\mathrm{i}}}{m}
$$

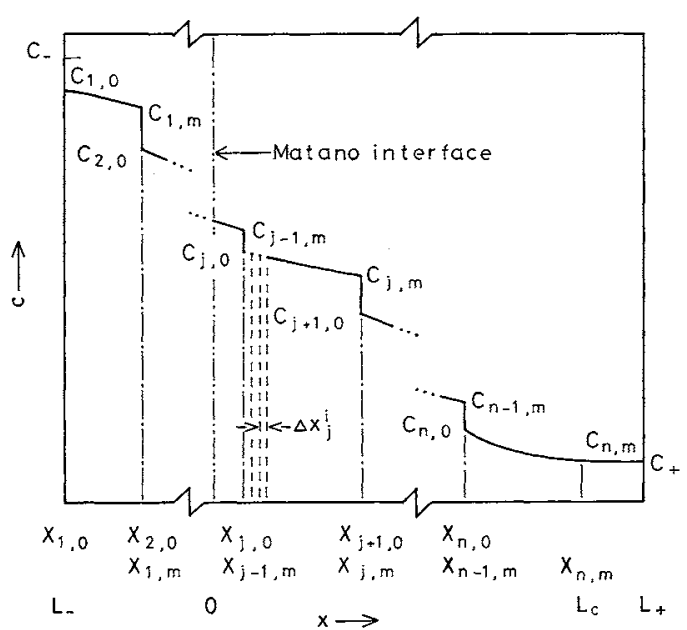

Fig. 1 Schematic representation of a finite/semi-infinite diffusion couple and symbols used.
によって表すことにする。ここで， $X_{\mathrm{j}, 0}^{\mathrm{i}}$ 括よび $X_{\mathrm{j}, \mathrm{m}}^{\mathrm{i}}$ は，

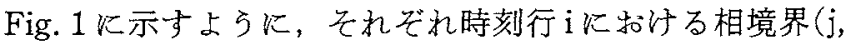

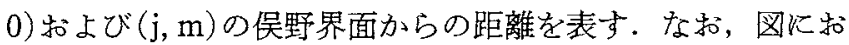
いて $L_{-}$和よび $L_{+}$は，それぞれ，桩散対左端および同右端 の俣野面からの距離を表す.

相 $\mathrm{j}$ に打ける距離刻みの順序数を, 一般的に， $k(\leqq m$, ミ0)によって表記すると, 試料左側からの距離刻みの覑序 数は $m(j-1)+k$ によって示されるが, 簡単のためにこれを (j,k)によって表すことにする。 また格子点は $[\mathrm{i},(\mathrm{j}, \mathrm{k})]$ に って表記する. 濃度の初期值，すなわち格子点 $[0,(\mathrm{j}, \mathrm{k})]$ に 対応寸る濃度 $C_{\mathrm{j}, \mathrm{k}}^{0}$ として次の二つの濃度一距離曲線上にある それらを考宎た。

(a) Fig. 2 に示すよらな，表面濃度 $C_{\mathrm{s}}$ が一定な条件で物 質が出入りする半無限拡散対の拡散時間 $t_{0}$ に怙ける濃度-距 離曲線.

(b) Fig. 3に示すような，二つの試料からなる拡散対に 招いて左端濃度が $\Delta c$ 一の濃度変化を起こした抆散時間 $t_{0} に$ 和ける濃度一距離曲線。

濃度としては単位体積中の拡散成分のモル数で定義した。な

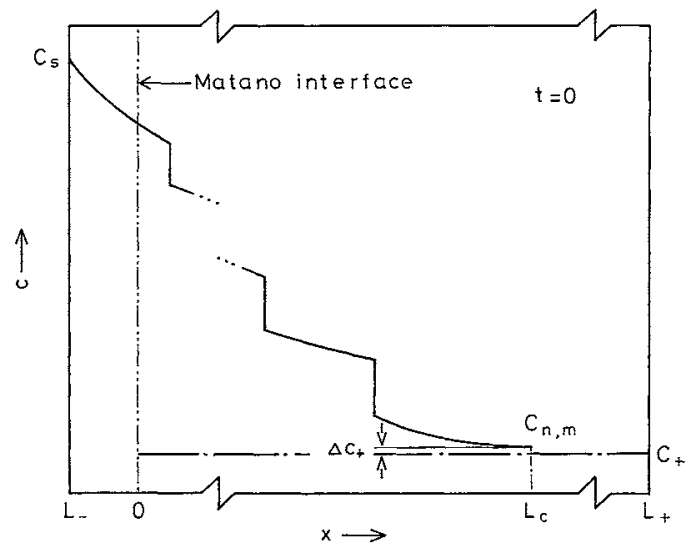

Fig. 2 Schematic representation of the initial condition for homogenization of a semi-infinite diffusion couple.

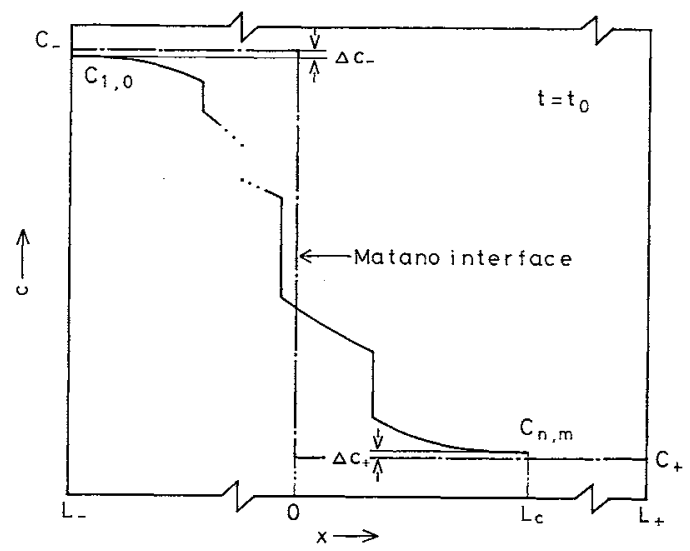

Fig. 3 Schematic representation of the initial condition for homogenization of a finite/semi-infinite diffusion couple. 
お，下記に特いては状況(a)を初期状態とする拡散対を半無限 均一化拡散対，状況(b)を初期状熊とする拡散対をめっき拡散 対と呼ぶことにする。

状況(a)に関する表面形成相，内部形成相特よび右端拡散相 での濃度は，それぞれ，次式で与えられる(2)。

$$
\begin{aligned}
c_{1, \mathrm{k}}^{0}= & c_{\mathrm{s}}-\frac{C_{\mathrm{s}}-C_{\mathrm{l}, \mathrm{m}}}{\operatorname{erf}\left(\omega_{1,0}\right)-\operatorname{erf}\left(\omega_{1, \mathrm{~m}}\right)} \\
& \times\left\{\operatorname{erf}\left(\omega_{1,0}\right)-\operatorname{erf}\left[\mathrm{x}_{\mathrm{l}, \mathrm{k}}^{0} /\left(4 \tilde{D}_{1} t_{0}\right)^{1 / 2}\right]\right\}, \\
L_{-} \leq & \mathrm{x} \leq X_{1, \mathrm{~m}}, \\
c_{\mathrm{j}, \mathrm{k}}^{0}= & C_{\mathrm{j}, 0}-\frac{C_{\mathrm{j}, 0}-C_{\mathrm{j}, \mathrm{m}}}{\operatorname{erf}\left(\omega_{\mathrm{j}, 0}\right)-\operatorname{erf}\left(\omega_{\mathrm{j}, \mathrm{m}}\right)} \\
& \times\left\{\operatorname{erf}\left(\omega_{\mathrm{j}, 0}\right)-\operatorname{erf}\left[\mathrm{x}_{\mathrm{j}, \mathrm{k}}^{0} /\left(4 \tilde{D}_{\mathrm{j}} t_{0}\right)^{1 / 2}\right]\right\}, \\
X_{\mathrm{j}, 0} \leq & \mathrm{x} \leq X_{\mathrm{j}, \mathrm{m}}, \\
c_{\mathrm{n}, \mathrm{k}}^{0}= & C_{+}+\frac{C_{\mathrm{n}, 0}-C_{+}}{1-\operatorname{erf}\left(\omega_{\mathrm{n}, 0}\right)} \cdot\left\{1-\operatorname{erf}\left[\mathrm{x}_{\mathrm{n}, \mathrm{k}}^{0} /\left(4 \tilde{D}_{\mathrm{n}} t_{0}\right)^{1 / 2}\right]\right\}, \\
X_{\mathrm{n}, 0} \leq & \mathrm{x} \leq L_{\mathrm{C}} .
\end{aligned}
$$

ここで，式(4)の $L_{\mathrm{C}}$ は相nの計算上での右端である.

一方，めっき拡散対の状況(b)に対応する初期拡散時間 $t_{0}$ は, Fig. 3 に示すょらに, $C_{1,0}^{0}$ として $\left(C_{-}-\Delta c_{-}\right)$を下式に 代入することによって求めた。状況(b)を初期濃度としたのは 計算時間をできるだけ短縮するためである。状況(b)に执ける 内部形成相牤よび右端拡散相での濃度は，半無限拡散対と同 じくれぞれ式(3)和よび（4)によって与えられるが，左 端拡散相での濃度に関しては次式によって与兄られる(1) (2).

$$
\begin{aligned}
& c_{1, \mathrm{k}}^{0}=C_{-}-\frac{C_{-}-C_{1, \mathrm{~m}}}{1+\operatorname{erf}\left(\omega_{1, \mathrm{~m}}\right)} \cdot\left\{1+\operatorname{erf}\left[\mathrm{x}_{1, \mathrm{k}}^{0} /\left(4 \tilde{D}_{1} t_{0}\right)^{1 / 2}\right]\right\}, \\
& L_{-} \leq \mathrm{x} \leq X_{1, \mathrm{~m}} .
\end{aligned}
$$

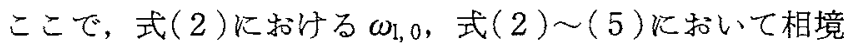
界濃度を表す下付き添兄字 $(\mathrm{j}, 0)$ 括よび $(\mathrm{j}, \mathrm{m})$ は，それどれ， 文献(1)(2)に持ける $\omega_{\mathrm{S}}$, 下付き添光字 $(\mathrm{j}, \mathrm{j}-1)$ 执よび $(\mathrm{j}, \mathrm{j}+1)$ に対応する。

\section{2. 均一化過程における拡散方程式}

仮定(1)〜(4)の下で濃度の初期值が式 (2)〜（4)または式 (3)〜 (5)で与えられる拡散対の均一化過程に颃いては, 上記仮定に引続き

（5）左端表面を出入りする拡散成分のモル数は 0 である。 といら条件下で拡散が進行すると仮定する，さらに拡散成分 の濃度変化が右端表面に及ぶ場合注は

(6) 右端表面を出入りする拡散成分のモル数は 0 である. ことを仮定する。

一方，仮定(3)が妥当と考えられる場合，各相内に和忷る相 互拡散は次の Fick の第 2 法則によって記述される。すなわ †

$$
\frac{\partial c}{\partial t}=\tilde{D}_{\mathrm{j}} \frac{\partial^{2} c}{\partial \mathrm{x}^{2}}
$$

多相拡散に扎いては，一般に相 $\mathrm{j}$ から異相界面 $\mathrm{j} / \mathrm{j}+1$ 一移転 した抬散成分のモル数は界面 $\mathrm{j} / \mathrm{j}+1$ から相 $\mathrm{j}+1$ へのモル数 K等しいので,

$$
\frac{\mathrm{d} X_{\mathrm{j}, \mathrm{m}}}{\mathrm{d} t}=\left\{\tilde{D}_{\mathrm{j}+1}\left(\frac{\partial c}{\partial \mathrm{x}}\right)_{\mathrm{i}+1,0}-\tilde{D}_{\mathrm{j}}\left(\frac{\partial c}{\partial \mathrm{x}}\right)_{\mathrm{j}, \mathrm{m}}\right\} /\left(C_{\mathrm{j}, \mathrm{m}}-C_{\mathrm{j}+1,0}\right)
$$

が成り立つ。

仮定 $(5)$ 力 5

$$
\tilde{D}_{1}\left(\frac{\partial c}{\partial \mathrm{x}}\right)_{1,0}=0
$$

な抏，Fig. 2 またはFig. 3 に特いて $L_{\mathrm{C}}=L_{+}$となったとき， この拡散対は右端に関して無限厚さから有限厚さになったも のと考える。このとき，仮定(6)から

$$
\tilde{D}_{\mathrm{n}}\left(\frac{\partial c}{\partial \mathrm{x}}\right)_{\mathrm{n}, \mathrm{m}}=0
$$

が成立する。

任意の異相界面 $X_{\mathrm{j}, 0}$ は俣野界面から観測すると, $\mathrm{d} X_{\mathrm{j}, 0} / \mathrm{d} t$ なる速度で移動している。この相境界の移動を考慮した Murray-Landis $の$ 可変格子(15)を用いると， $X_{\mathrm{j}, \mathrm{k}}$ に抢ける濃 度の時間変化は，

$$
\frac{\mathrm{d} c_{\mathrm{j}, \mathrm{k}}}{\mathrm{d} t}=\frac{\partial c_{\mathrm{j}, \mathrm{k}}}{\mathrm{dx}} \cdot \frac{\mathrm{dx}_{\mathrm{j}, \mathrm{k}}}{\mathrm{d} t}+\frac{\partial c_{\mathrm{j}, \mathrm{k}}}{\partial t}
$$

によって表される

\section{3. 差分方程式}

相境界 $(\mathrm{j}, \mathrm{m})$ が俣野界面から移動する速度は

$$
\frac{\mathrm{d} X_{\mathrm{j}, \mathrm{m}}^{\mathrm{i}+1}}{\mathrm{~d} t}=\frac{X_{\mathrm{j}, \mathrm{m}}^{\mathrm{i}+1}-X_{\mathrm{j}, \mathrm{m}}^{\mathrm{i}}}{\Delta t^{\mathrm{i}}}
$$

によって定義される。ここで $\Delta t^{\mathrm{i}}$ は時間行 $\mathrm{i}$ と時間行 $\mathrm{i}+1$ との時間幅を表し，上付きのiはこの時間幅が一般に拡散時 間とともに変動することを表す。一方，この速度は，式(7) を4点公式を用いて差分化した次式によって表すことがで きる・すなわち

$$
\begin{aligned}
\frac{\mathrm{d} X_{\mathrm{j}, \mathrm{m}}^{\mathrm{i}+1}}{\mathrm{~d} t}= & \frac{1}{C_{\mathrm{j}, \mathrm{m}}-C_{\mathrm{i}+1,0}} \cdot\left[\tilde{D}_{\mathrm{j}+1}\right. \\
& \times \frac{2 c_{\mathrm{j}+1,3}^{\mathrm{i}}-9 c_{\mathrm{j}+1,2}^{\mathrm{i}}+18 c_{\mathrm{j}+1,1}^{\mathrm{i}}-11 c_{\mathrm{j}+1,0}^{\mathrm{i}}}{6 \Delta \mathrm{x}_{\mathrm{j}+1}^{\mathrm{i}}} \\
& \left.-\tilde{D}_{\mathrm{j}} \cdot \frac{-2 c_{\mathrm{j}, \mathrm{m}-3}^{\mathrm{i}}+9 c_{\mathrm{j}, \mathrm{m}-2}^{\mathrm{i}}-18 c_{\mathrm{j}, \mathrm{m}-1}^{\mathrm{i}}+11 c_{\mathrm{j}, \mathrm{m}}^{\mathrm{i}}}{6 \Delta \mathrm{x}_{\mathrm{j}}^{\mathrm{i}}}\right], \\
& \mathrm{j}=1,2, \cdots, \mathrm{n}-1 .
\end{aligned}
$$

相互搪散係数が濃度に依存しない場合の Fickの第 2 法 則，すなわら武(6)は陽解法 (16)基づくと

$$
\frac{\partial c_{\mathrm{j}, \mathrm{k}}}{\partial t}=\tilde{D}_{\mathrm{j}} \frac{c_{\mathrm{i}, \mathrm{k}-1}^{\mathrm{i}}-2 c_{\mathrm{j}, \mathrm{k}}^{\mathrm{i}}+c_{\mathrm{j}, \mathrm{k}+1}^{\mathrm{i}}}{\left(\Delta \mathrm{x}_{\mathrm{j}}^{\mathrm{i}}\right)^{2}}
$$

によって記述される。一方, 式(10)の左辺の項扣よび右边 第 1 項は，それぞれ

$$
\begin{aligned}
\frac{\mathrm{d} c_{\mathrm{j}, \mathrm{k}}}{\mathrm{d} t} & =\frac{c_{\mathrm{j}, \mathrm{k}}^{\mathrm{i}+1}-c_{\mathrm{j}, \mathrm{k}}^{\mathrm{i}}}{\Delta t^{\mathrm{i}}}, \\
\frac{\partial c_{\mathrm{j}, \mathrm{k}}}{\partial \mathrm{x}_{\mathrm{j}}} & =\frac{c_{\mathrm{j}, \mathrm{k}+1}^{\mathrm{j}}-c_{\mathrm{j}, \mathrm{k}-1}^{\mathrm{i}}}{2 \Delta \mathrm{x}_{\mathrm{j}}^{\mathrm{i}}} .
\end{aligned}
$$

また, 式(10)の右辺第 1 項右側は次の差分式に変換される。 すなわち 


$$
\frac{\mathrm{dx}_{\mathrm{j}, \mathrm{k}}}{\mathrm{d} t}=\frac{\mathrm{d} X_{\mathrm{j}, 0}^{\mathrm{i}+1}}{\mathrm{~d} t}+\frac{\mathrm{x}_{\mathrm{j}, \mathrm{k}}^{\mathrm{i}}-X_{\mathrm{j}, 0}^{\mathrm{i}}}{X_{\mathrm{j}, \mathrm{m}}^{\mathrm{i}}-X_{\mathrm{j}, 0}^{\mathrm{i}}} \cdot\left(\frac{\mathrm{d} X_{\mathrm{j}, \mathrm{m}}^{\mathrm{i}+1}}{\mathrm{~d} t}-\frac{\mathrm{d} X_{\mathrm{j}, 0}^{\mathrm{i}+1}}{\mathrm{~d} t}\right) .
$$

上式は, 式(1)から明らかなよう飞，一般次式によって 表すことができる.すなわら

$$
\frac{\mathrm{dx}_{\mathrm{j}, \mathrm{k}}}{\mathrm{d} t}=\frac{\mathrm{d} X_{\mathrm{j}, 0}^{\mathrm{i}+1}}{\mathrm{~d} t}+\frac{k}{m} \cdot\left(\frac{\mathrm{d} X_{\mathrm{j}, \mathrm{m}}^{\mathrm{i}+1}}{\mathrm{~d} t}-\frac{\mathrm{d} X_{\mathrm{j}, 0}^{\mathrm{i}+1}}{\mathrm{~d} t}\right) .
$$

式(13)，(14)，(15)㸱よび(17)を式(10)に代入すると，一般 飞, 時刻行 $\mathrm{i}+1$ 飞物斿る距離刻及 $(\mathrm{j}, \mathrm{k})$ での濃度は

$$
\begin{aligned}
c_{\mathrm{j}, \mathrm{k}}^{\mathrm{i}+1}= & c_{\mathrm{j}, \mathrm{k}}^{\mathrm{i}}+\frac{c_{\mathrm{j}, \mathrm{k}+1}^{\mathrm{j}}-c_{\mathrm{j}, \mathrm{k}-1}^{\mathrm{i}}}{2 \Delta \mathrm{x}_{\mathrm{j}}^{\mathrm{i}}} \cdot\left\{\frac{\mathrm{d} X_{\mathrm{j}, 0}^{\mathrm{i}+1}}{\mathrm{~d} t}+\frac{k}{m} \cdot\left(\frac{\mathrm{d} X_{\mathrm{j}, \mathrm{m}}^{\mathrm{i}+1}}{\mathrm{~d} t}-\frac{\mathrm{d} X_{\mathrm{j}, 0}^{\mathrm{j}+1}}{\mathrm{~d} t}\right)\right\} \\
& \times \Delta t^{\mathrm{i}}+\gamma_{\mathrm{j}}^{\mathrm{i}}\left(c_{\mathrm{j}, \mathrm{k}-1}^{\mathrm{i}}-2 c_{\mathrm{j}, \mathrm{k}}^{\mathrm{i}}+c_{\mathrm{j}, \mathrm{k}+1}^{\mathrm{i}}\right)
\end{aligned}
$$

火よって与完られる。

上式の $\gamma^{i}$ は

$$
\gamma_{\mathrm{j}}^{\mathrm{i}}=\tilde{D}_{\mathrm{j}} \cdot \frac{\Delta t^{\mathrm{i}}}{\left(\Delta \mathrm{x}_{\mathrm{j}}^{\mathrm{i}}\right)^{2}}
$$

によって定義される.

ここで，上式の $\Delta t^{\mathrm{i}}$ は次のようにして定めたますず， $\gamma_{0} を$ 0.5以下の任意の值に設定した次式，すなわち

$$
\Delta t_{\mathrm{j}}^{\mathrm{j}}=\gamma_{0} \cdot \frac{\left(\Delta \mathrm{x}_{\mathrm{j}}^{\mathrm{j}}\right)^{2}}{\tilde{D}_{\mathrm{j}}}
$$

から，すべての相炕関する時間刻み幅を定める。次に，先れ らの中で最も小さい値を $\Delta t^{\mathrm{i}}$ として採用した。すなわち

$$
\Delta t^{\mathrm{i}}=\operatorname{MIN}\left(\Delta t_{\mathrm{j}}^{\mathrm{j}}\right) \text {. }
$$

均一化搪散時間 $t$ は $\Delta t^{\mathrm{i}}$ の総和炏等しいので, 次式が成立す る.

$$
t=\sum_{\mathrm{i}} \Delta t^{\mathrm{i}}
$$

一方, 時刻行 $i+1 の \mathrm{x}=L_{-}$および $\mathrm{x}=L_{+}$に括ける濃度 は，差分式(12)k括いて，濃度勾配を表す項を 0 とおいた 式，すなわち

$$
\begin{aligned}
C_{1,0}^{\mathrm{i}+1} & =\frac{18 C_{1,1}^{\mathrm{i}+1}-9 C_{1,2}^{\mathrm{i}+1}+2 C_{1,3}^{\mathrm{i}+1}}{11}, \\
C_{\mathrm{n}, \mathrm{m}}^{\mathrm{i}+1} & =\frac{18 C_{\mathrm{n}, \mathrm{m}-1}^{\mathrm{i}+1}-9 C_{\mathrm{n}, \mathrm{m}-2}^{\mathrm{i}+1}+2 C_{\mathrm{n}, \mathrm{m}-3}^{\mathrm{i}+1}}{11}
\end{aligned}
$$

によって与充られる。

\section{4、計算上での留意点および計算の流れ}

相 $\mathrm{n}$ の計算上の右端として拡散対の右端 $L_{+}$を考劣ると， 計算の初期に特いては相nの殆どの距離刻みに扎いて浱度 は $C_{+}$となる.このことは式(12)によって与兄られる相境界 $(\mathrm{n}-1, \mathrm{~m})$ の移動速度が必ずしも正確ではないことを意味 し，これを避忖るためには距離行分割数 $m$ を大きくする必 要がある。しかし，このことは式(1)扣よび(20)から明ら かなように時間刻みが小さくなること，すなわち繰り返し計 算の回数が増克，計算時間が長くなることを意味する。した がって、ここでは相 $\mathrm{n}$ の計算上の右端 $L_{\mathrm{C}}$ は次の上うに拡散 時間の関数として与えることにした。すなわち，距離刻及 (n, m) 飞和汀る濃度として Fig. 2 または Fig. 3 亿示すよう な $\left(C_{+}+\Delta c_{+}\right)$を考克，この値を式 (4) 亿代入して得られる
[ ]内の值を $\eta_{\mathrm{C}}$ とすと， $L_{\mathrm{C}}$ は次式によって与光られる。 すなわち

$$
L_{\mathrm{C}}=X_{\mathrm{n}, \mathrm{m}}^{\mathrm{i}}=\eta_{\mathrm{C}}\left\{4 \widetilde{D}_{\mathrm{n}}\left(t_{0}+t\right)\right\}^{1 / 2} .
$$

一方, 仮定(5)火基づくと, 表面相 1 飞関しては, 搪散対 の左端表面を出入りする拡散成分のモル数は 0 である。し かし, 内部隣接相に向かっては絶光ざるモル移動の流れが存 在する。したがって，拡散時間が十分に長い場合には，表面 相の層幅は漸次薄くなり，ついには消失していくことにな

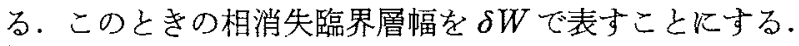

上記差分式を用いた遂次繰り返し計算の流れを筬条書をに して以下に示す。

（1）半無限拡散対飞ついては，与兄られた初期濃度，相境 界濃度, 相境界飞関するパラメータ $\omega$, 相互拡散保数括上 び搪散浸透時間 $t_{0}$ を用いて，式 (2)，(3)括よび $(4)$ から， 各格子点 $[0,(\mathrm{j}, \mathrm{k})]$ に招りる濃度を計算する。如拡散対 については, 状沉(b)に対応する桩散時間 $t_{0}$ と, 半無限执散 対を同样なデータを用いて，式(5)，(3)和よび（4)から各 格子点炕指初期濃度を計算する。

次に，位置 $L_{-}$から俣野界面に至るまでの距離, および 俣野界面から相境界 $(1,0)$ 拉よび $(\mathrm{j}, \mathrm{m})$ に至るまでの距離を, それぞれ，

$$
\begin{aligned}
& L_{-}=X_{1,0}^{0}=\omega_{1,0}\left(4 \tilde{D}_{1} t_{0}\right)^{1 / 2}, \\
& X_{\mathrm{j}, \mathrm{m}}^{0}=\omega_{\mathrm{j}, \mathrm{m}}\left(4 \tilde{D}_{\mathrm{j}} t_{0}\right)^{1 / 2}
\end{aligned}
$$

から計算する。位置 $L_{\mathrm{C}}$ 関する距離は $t=0$ とおいた式 （25）から計算する。广お，めっき拡散対の場合の $L-$ はめっ き層の厚さを表す。

(2) 仮定(4)加ら

$$
X_{\mathrm{j}, 0}^{\mathrm{i}}=X_{\mathrm{j}-1, \mathrm{~m}}^{\mathrm{i}}
$$

が成立し(1)(2)，時刻行 $\mathrm{i}$ 亿関する $X_{\mathrm{j}, 0}(\mathrm{j}=2,3,4, \ldots, \mathrm{n})$ が与 えられる。

(3) 式(1)，(20)括上び(21)加ら $\Delta t_{\mathrm{i}}$ を求め，式(19)から 時刻行 $\mathrm{i}$ 火関する $\gamma_{\mathrm{j}}$ を求める.

（4）式(12)加時間行 $\mathrm{i}+1$ 亿関与る相境界 $X_{\mathrm{j}, \mathrm{m}}$ の移動速 度を求める. $X_{1,0}$ の移動速度, 括上び $L_{\mathrm{C}}=L_{+}$の場合の $X_{\mathrm{n}, \mathrm{m}}$ の移動速度は，とれらの相境界が俣野界面に固定され ているので, 值 0 を代入する. $L_{\mathrm{C}}<L_{+}$の場合, 時刻行 $\mathrm{i}+1$ 亿指ける $X_{\mathrm{n}, \mathrm{m}}$ の值を式(27)加求め, これを式(11) 火 代入することによって $X_{\mathrm{n}, \mathrm{m}}$ の移動速度を求める.なお, 式 (28)加ら明らかな上らに, 相境界 $X_{\mathrm{j}, \mathrm{m}}$ の移動速度は $X_{\mathrm{j}+1,0}$ のそれに等しい.

(5) 式(11) 飞，時刻行 $\mathrm{i}+1$ 亿㕲ける $\mathrm{d} X_{\mathrm{j}, \mathrm{m}} / \mathrm{d} t$ および $\Delta t_{\mathrm{i}}$ を代入して，時刻行 $\mathrm{i}+1$ 亿括讨る $X_{\mathrm{j}, \mathrm{m}}$ を求める.

(6) 時刻行iに招ける濃度, パラメータ $\gamma_{\mathrm{j}}$ 蚛よび時刻行 $i+1$ 火和ける相境界移動速度を式(18) 代入して, 時刻行 $i+1$ 亿打ける濃度を求める。 $X_{1,0}$ 打よび $L_{\mathrm{C}}=L_{+}$の場合の

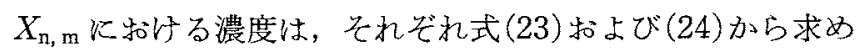
る. $L_{\mathrm{C}}<L_{+}$の場合, $X_{\mathrm{n}, \mathrm{m}}$ の濃度は $C_{+}+\Delta c_{+}$によって定義 される。

（7）表面相の層幅が $\delta W$ 以下の場合，表面相は消失した 
ものとみなし，内部隣接相を表面相とする。また，式(22) が成立した場合には計算は終了する，とちでない場合には時 間行 i+1を新しい時間行 i として過程(3)に戻る。

なお，めっき拡散対の相 1 なたは相 $\mathrm{n}$ の領域において， ならびに半無限均一化拡散対の相 $\mathrm{n}$ の領域に抏いて，拡散 による濃度変化が殆ど認められない場合，それぞれの領域に 招いては次式が成立する。すなおち

$$
\begin{aligned}
& \text { ここk, } k=1,2, \cdots, m-1, c_{1}^{\mathrm{k}}=C_{-} \\
& \text {ここk, } k=2,3, \cdots, m .
\end{aligned}
$$

この場合, 異相界面 $1 / 2$ 特よび $(\mathrm{n}-1) / \mathrm{n}$ に拈㹁るモル収支 の式(7)は，それぞれ

$$
\frac{\mathrm{d} X_{1, \mathrm{~m}}^{\mathrm{i}+1}}{\mathrm{~d} t}=\frac{1}{C_{-}-C_{2,0}} \cdot \tilde{D}_{2} \cdot \frac{2 c_{2,3}^{\mathrm{i}}-9 c_{2,2}^{\mathrm{i}}+18 c_{2,1}^{\mathrm{i}}-11 c_{2,0}^{\mathrm{i}}}{6 \Delta \mathrm{x}_{2}^{\mathrm{i}}}
$$

および

$$
\begin{aligned}
\frac{\mathrm{d} X_{\mathrm{n}-1, \mathrm{~m}}^{\mathrm{i}+1}}{\mathrm{~d} t}= & \frac{-1}{C_{\mathrm{n}-1, \mathrm{~m}}-C_{+}} \cdot \tilde{D}_{\mathrm{n}-1} \\
& \times \frac{-2 c_{\mathrm{n}-1, \mathrm{~m}-3}^{\mathrm{i}}+9 c_{\mathrm{n}-1, \mathrm{~m}-2}^{\mathrm{i}}-18 c_{\mathrm{n}-1, \mathrm{~m}-1}^{\mathrm{i}}+11 c_{\mathrm{n}-1, \mathrm{~m}}^{\mathrm{i}}}{6 \Delta \mathrm{x}_{\mathrm{n}-1}^{\mathrm{i}}}
\end{aligned}
$$

の差分式によって表すことができる.

式(29)特よび(31)を適用しなければならない状沇として は

$$
C_{-}-C_{1, \mathrm{~m}}<\delta_{\mathrm{C}}
$$

または

$$
\omega_{1, \mathrm{~m}}<-\Omega_{\max }
$$

を考光る。ここに， $\delta_{\mathrm{C}}$ は十分に小さい值の濃度幅， $\Omega_{\max }$ は 十分火大きい正の值とする。式(30)和よび(32)を適用しな ければならない状況として子，同様に，以下の条件を考觉 万.

$$
C_{\mathrm{n}, 0}-C_{+}<\delta_{\mathrm{C}}
$$

または

$$
\omega_{\mathrm{n}, 0}>\Omega_{\max }
$$

\section{III． 数値計算結果の検証と考察}

本数値解析が 2 元系多相桩散対に括ける濃度の均一化過 程に関して与光る情報について，実験結果との対比を行いな がら、様々な観点から検討特よび考察を行った。また，種及 の多相拡散現象をシミュレートするためには，II．数値解析 で与光た基本的な数值解析のみでは不十分であるので，上記 解析にいくつかの補足を行った．検証は三つの型の㹡散対， すなわち半無限均一化拡散対，めっき拡散対扣よび薄膜/薄 膜桩散対に関して行った。

\section{1. 半無限拡散対}

半無限均一化拡散対に関する計算例として Al-Ni 系を取り 上げた。 入力值としての相互桩散係数, 相境界組成, 括よび
Table 1 Phase boundary compositions ${ }^{(17)} N$ and interdiffusion coefficients $\tilde{D}$, and obtained parameters $\omega$ for the Boltzmann type of semi-infinite couple in the $\mathrm{Al}_{3} \mathrm{Ni}_{2}-\mathrm{AlNi}_{\mathrm{N}} \mathrm{AlNi}_{3}-(\mathrm{Ni})$ system at $1043 \mathrm{~K}$. These values were used for calculating Figs. 4 and 5 .

\begin{tabular}{l|rr|c|c|c}
\hline \hline Phase(j) & \multicolumn{2}{|c|}{$\begin{array}{c}N_{\mathrm{j}, 0} \\
\text { (at\% } \% N_{\mathrm{j}, \mathrm{m}}\end{array}$} & $\begin{array}{c}\tilde{D}_{\mathrm{j}} \\
\left(\mathrm{m}^{2} / \mathrm{s}\right)\end{array}$ & $\omega_{\mathrm{j}, 0}$ & $\omega_{\mathrm{j}, \mathrm{m}}$ \\
\hline $\mathrm{Al}_{3} \mathrm{Ni}_{2}(1)$ & 63.8 & 59.5 & $2.1 \times 10^{-12(3)}$ & -0.2206 & 0.0805 \\
$\mathrm{AlNi}(2)$ & 56.6 & 38.2 & $1.5 \times 10^{-14(3)}$ & 0.953 & 1.097 \\
$\mathrm{AlNi}_{3}(3)$ & 26.8 & 25.6 & $1.5 \times 10^{-15(18)}$ & 3.467 & 3.473 \\
$\left(\mathrm{Ni}^{2}\right)(4)$ & 12.4 & 0.0 & $2.6 \times 10^{-16(18)}$ & 8.342 & \\
\hline
\end{tabular}

これらの值を用いて計算(2)(3) した式 (2)，(3)特よび(4)中 のパラメータ $\omega$ の值を Table 1 亿示寺。なお計算に沶いて は表面組成は相境界 $\left(\mathrm{Al}_{3} \mathrm{Ni}+\mathrm{Al}_{3} \mathrm{Ni}_{2}\right) / \mathrm{Al}_{3} \mathrm{Ni}_{2}$ に和ける組成に 等しいと考光， $\mathrm{Al}$ 扣よび $\mathrm{Ni}$ の部分モル体積として10.0和よ び $6.6 \mathrm{~cm}^{3} / \mathrm{mol}$ を用いた。ささらに，表面に物いては苲発な ぞによる Ni 原子の試料内部から外部への移転はないものと 仮定した。本系の半無限拡散対に関しては, 既に, Hickl Hecke1 ${ }^{(3)}$ が実験結果特よび数值計算結果の雨面から，層成 長・衰微挙動について詳細に娭討している。ここでは， Hickl らの結果と比較検討するため住として彼らが使用 した相互拡散係数を計算に用いた。また，Table 1 に示した $\omega_{1,0}$ の值は距離座標の原点位置, 換言すれば Al 原子の漫透 に伴う試料厚さの増加量を与える.さらに, Table 1 の計算 結果以外飞質量増加速度常数 ${ }^{(2)}$ とて $0.235 \mathrm{~g} /\left(\mathrm{s}^{1 / 2} \mathrm{~m}^{2}\right)$ を得 た。

表面形成相和よび内部形成相の各層内に括ける濃度初期值 は，Table 1 の $\omega_{\mathrm{j}, 0}$ 扎よび $\omega_{\mathrm{j}, \mathrm{m}}$ を，それぞれ，式(2)およ び( 3 ) に代入することによって得られる。しかし，端末相 すなわち(Ni) 相関しては, Table 1 の $\omega_{4,0}$ を式(4)火代 入すると， $\omega_{4,0}$ の值が大きすぎて濃度初期值を求めること は困難である.一方， $\omega_{4,0}$ は，例光ば式(27)から明らかな ように相互拡散係数の平方根に逆比例するので，(Ni)相の 相互桩散係数が小さいと，逆に大きな值を示す。したがっ て， $\Omega_{\max }$ が十分に大きい正の值であり，かつ式(36)が満足 される場合，相 $\mathrm{n}$ 飞执いては，拡散によって生じる濃度変 化は観測されない程度に小さいと考えても差し支皃ない。し たがって，異相界面に乱ける質量保存則を記述する式とし て，式(12)の代わりに式(32)を用いた。 李た，本研究に拉 いては $\Omega_{\max }$ の值として3.5を考克た。

各層の距離刻文数 $m$ を15，パラメータ $\gamma$ を0.48kとり， 拡散浸透後の均一化過程のシミュレーションを行った。得ら れた $\mathrm{Al}_{3} \mathrm{Ni}_{2}$ 牤よび $\mathrm{AlNi}$ 相の層幅ならびに全体としての層幅 の時間変化を Fig. 4 に示す。図から明らかなように，全体 としての層幅は均一化拡散時間に殆ど依存することなくほぼ 一定であり，22.5 ks の均一化拡散時間に拈いても全体とし ての層幅がわずか 7\%程度増加するに過ぎない，また，図に は示していないが， $\mathrm{AlNi}_{3}$ 相に関しては層幅の増加率は大き いものの，22.5 ksに扎いて子僅か $0.4 \mu \mathrm{m} の$ 值であり，全 
体の層幅に比較すると無視できる厚さである．したがって， 図に扣いて $\mathrm{Al}_{3} \mathrm{Ni}_{2}$ 相の層幅の減少分と $\mathrm{AINi}$ 相の層幅の増加 分が注注等しいという興味ある拡散現象を呈している。 た，図に执いて実験結果(3)もこのことを裏付けている。

上記の均一化過程の層成長・哀微挙動以ついて以下に考察 する. $\mathrm{AlNi}_{3}$ 相は極めて薄い層なので，層内での濃度勾配が 他の相に比較して非常に大きいことは十分に確かなことであ る.しかし, $\mathrm{AlNi}_{3}$ 相の相互拡散係数が $\mathrm{Al}_{3} \mathrm{Ni}_{2}$ 相打よび $\mathrm{AlNi}$ 相のそれらに比較して非常に小さいことならびに相 境界 $\mathrm{AlNi}_{3} /\left(\mathrm{AlNi}_{3}+(\mathrm{Ni})\right)$ K括ける $\mathrm{Al}$ 濃度がかなり大さな 值を持つことを考慮すると，異相界面 $\mathrm{AlNi}_{3} /(\mathrm{Ni})$ の移動速

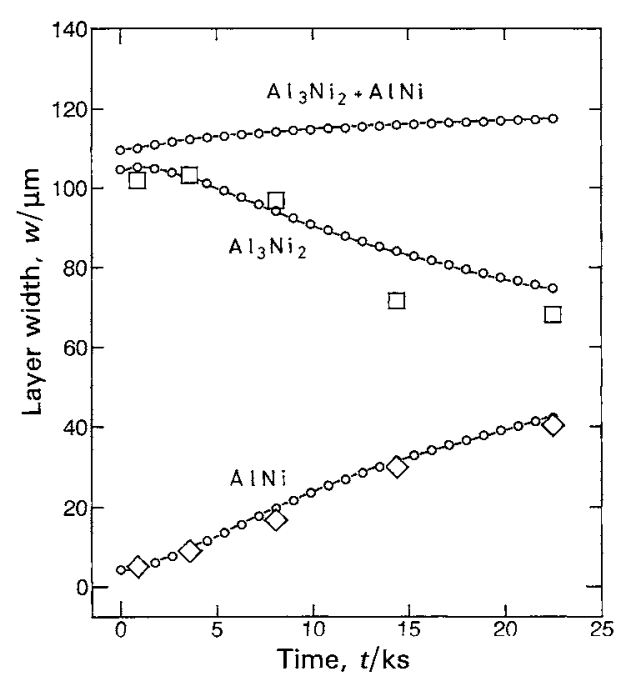

Fig. 4 Time dependence of widths of intermediate phase layers for a homogenization treatment at $1143 \mathrm{~K}$ after the aluminizing of nickel at $1143 \mathrm{~K}$ for $14.4 \mathrm{ks}$. The symbols $\square$ and $\diamond$ stand for experimental values ${ }^{(3)}$ for phases $\mathrm{Al}_{3} \mathrm{Ni}_{2}$ and $\mathrm{AINi}$, respectively.

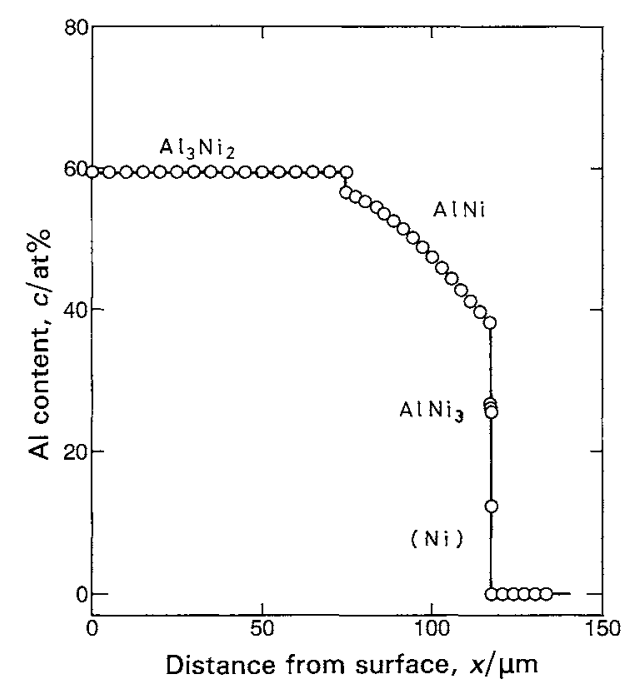

Fig. $5 \mathrm{Al}$ content profile for a homogenization treatment at $1143 \mathrm{~K}$ for $22.5 \mathrm{ks}$, after the aluminizing of nickel at $1143 \mathrm{~K}$ for $14.4 \mathrm{ks}$.
度が極めて小さい值を取ることが式(32)から理解される。 したがって, 全体としての層幅が均一化挫散時間と無関係に 活注一定であるのは，このように界面 $\mathrm{AlNi}_{3} /(\mathrm{Ni})$ の移動速 度が極めて小さいことによるものである。

一方, 表面に和ける $\mathrm{Al}$ 濃度は均一化拡散の開始とともに 急速に減少し, 約 $10 \mathrm{ks}$ で $\mathrm{Al}_{3} \mathrm{Ni}_{2}$ 相層内に括りる濃度変化 は認めら就なくる.そして22.5 ksでは，Fig. 5 に示すよ $5 \mathrm{~K}, \mathrm{Al}_{3} \mathrm{Ni}_{2}$ 相の層内濃度は相境界 $\mathrm{Al}_{3} \mathrm{Ni}_{2} /\left(\mathrm{Al}_{3} \mathrm{Ni}_{2}+\mathrm{AlNi}\right)$ に指ける濃度に等しく，距離軸に平行な濃度-距離曲線を描 く.したがって，式（7）に特いて\{\}内の第2 項を無視す ることができ, 界面 $\mathrm{Al}_{3} \mathrm{Ni}_{2} / \mathrm{AlNi} の$ 移動速度は相境界 $\left(\mathrm{Al}_{3} \mathrm{Ni}_{2}+\mathrm{AlNi}\right) / \mathrm{AlNi}$ 近くの濃度勾配のみに依存することが

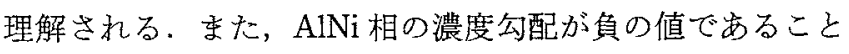
を考觉ると，この界面は表面に向かって移動すること，すな わち $\mathrm{Al}_{3} \mathrm{Ni}_{2}$ 相の層幅が減少していくことが明らかである.

\section{2. めっき拡散対}

めっき桩散対の例として Al-Fe 系を取り上げた。計算に 用いた各相の相互拡散係数括上び相境界組成を Table 2 に 示す。たたし， $\mathrm{A} 1$ 扎よび Feの部分モル体積はそれぞれ10.0 および $7.1 \mathrm{~cm}^{3} / \mathrm{mol}$ であり, $\mathrm{Al}$ 薄膜の厚さは $3 \mu \mathrm{m}$, 均一化 执散温度は $1273 \mathrm{~K}$ を仮定した。 なた， $(\gamma \mathrm{Fe})$ 相の相互拡散 係数は求められていないが，Feの自己桩散係数に関して $1123 \mathrm{~K}$ ではあるが $\mathrm{D}(\alpha) / \mathrm{D}(\gamma) \fallingdotseq 10^{2}$ であることが報告され ている(24)。したがって，ここでは $(\gamma \mathrm{Fe})$ 相の D は $(\alpha \mathrm{Fe})$ 相 のそれの100倍でめると考光た值を用いた．Fig. 3 に抏いて $\Delta c_{-}$を 0.05 at\% Al に対応する濃度にとると, 薄膜の表面 $\mathrm{Al}$

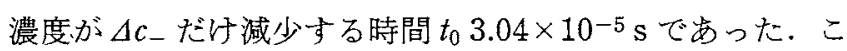
のとき, あらかじめ行った計算の結果 ${ }^{(1)(2)}$, 中間相の中で最 も大さな層成長速度常数を持つ $\mathrm{Fe}_{2} \mathrm{Al}_{5}$ 相の層幅は7.28× $10^{-5} \mu \mathrm{m}$ である。この值を式(20)に代入して時間刻み幅を

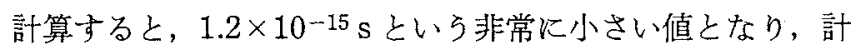
算時間が極めて長時間となる。ただし，距離分割数を15と

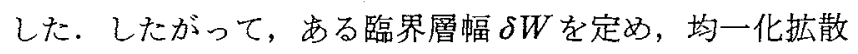

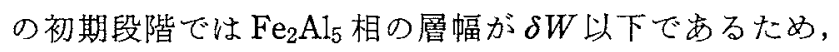
$\mathrm{Fe}_{2} \mathrm{Al}_{5}$ 相和よび他の中間相は昖散対に存在しないと仮定し， 拡散対は液相扣よび $(\gamma \mathrm{Fe})$ 相からなる2相系を考えた。また

Table 2 Phase boundary compositions ${ }^{(19)} N$ and interdiffusion coefficients $\widetilde{D}$, and obtained parameters $\omega$ for the Boltzmann type of infinite couple in the [A1]- $(\gamma \mathrm{Fe})$ system at $1273 \mathrm{~K}$. These values were used for calculating Figs. 6, 7 and 9.

\begin{tabular}{|c|c|c|c|c|c|}
\hline Phase (j) & $\begin{array}{r}N_{\mathrm{j}, 0} \\
\quad \text { at }\end{array}$ & $\begin{array}{l}N_{\mathrm{f}, \mathrm{m}} \\
\text { 1) }\end{array}$ & $\begin{array}{c}\tilde{D}_{\mathrm{j}} \\
\left(\mathrm{m}^{2} / \mathrm{s}\right)\end{array}$ & $\omega_{\mathrm{j}, 0}$ & $\omega_{j, \mathrm{~m}}$ \\
\hline [Al] (1) & 100.0 & 91.1 & $2.11 \times 10^{-08(20)}$ & - & 0.03749 \\
\hline $\mathrm{Al}_{3} \mathrm{Fe}$ (2) & 76.0 & 74.5 & $1.00 \times 10^{-11(21)}$ & - & - \\
\hline $\mathrm{Al}_{5} \mathrm{Fe}_{2}(3)$ & 72.6 & 70.0 & $4.74 \times 10^{-10(22)}$ & - & - \\
\hline $\mathrm{Al}_{2} \mathrm{Fe}$ (4) & 66.8 & 66.0 & $2.04 \times 10^{-12(21)}$ & - & - \\
\hline$(\alpha \mathrm{Fe})(5)$ & 53.4 & 1.7 & $2.59 \times 10^{-13(23)}$ & - & - \\
\hline$(\gamma \mathrm{Fe})(6)$ & 1.2 & 0.0 & $2.59 \times 10^{-15}$ & 107.0 & - \\
\hline
\end{tabular}

The bracket[ ]means lipuid. 
Botzmann 型無限拡散対に関して計算(1)によって求めたパラ メータ $\omega_{1, \mathrm{~m}}$ 抌よび $\omega_{2,0}$ の值を Table 2 に示す。

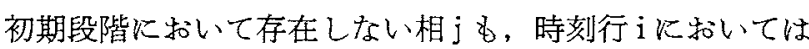
$\delta W$ の層幅を持ち，その層内では濃度距離曲線は直線的であ ると仮定し，計算の流れ(4)括よび(5)に従って時刻行 $(i+1)$ に 特ける層幅 $W_{\mathrm{j}}(\mathrm{i}+1)$ を求める。ここで

$$
W_{\mathrm{j}}(\mathrm{i}+1)>R \cdot \delta W
$$

を満足し，かつ上式を満足するいくつかの相の中で最も大き な層幅を持つ相のみが新たに拡散領域に出現すると考古た。 また，本拡散対に関しては臨界層幅 $\delta W$ 打よびRとしてそ れぞれ $0.1 \mu \mathrm{m}$ 打よび1.2を採用した．新相の出現の上記確 認を各時間行に和いて行らと，計算時間がかかり過ぎるの で，時間間隔 $\delta t=0.01 \mathrm{~s}$ 每に行らことにした。 なた，拡散 の進行とともに端末相の層幅 $W_{\mathrm{j}}(\mathrm{i})$ が臨界層幅より小さい場 合には，すなわち

$$
W_{\mathrm{j}}(\mathrm{i})<\delta W
$$

である場合には，その端末相 $\mathrm{j} は$ は消失したと判断した。ただ し，拡散詨から端末相が消失することはあり得ても，端末相 でない中間相が消失することはあり得ないと考えた。

上記の $\omega_{1, \mathrm{~m}}$ 特よび $t_{0}$ の值を式 $(5)$ に代入し，Al薄膜内 の各格子点に拈初期濃度を求めた。一方， $\omega_{2,0}$ の值が

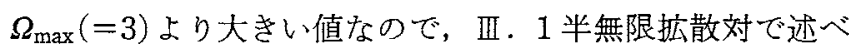
たと同様に， $(\gamma \mathrm{Fe})$ 相内の格子点濃度は $C_{2,0}$ を除いて $C_{+}$, すなわち0と考えた。上記初期濃度および Table 2 の值を 用いて求めた，拡散時間 $26.4 \mathrm{~s}$ に至るまでの新相の出現和 よび既存相の消失状況をFig. 6 に示す。な牤，図に牤いて は $\mathrm{FeAl}_{3}$ 相は拡散領域中に出現しないが， $\delta W の$ 值として $0.03 \mu \mathrm{m}$ を採用すると最大值 $0.06 \mu \mathrm{m}$ の值を持って出現す るが，この程度の層幅では実際上拡散領域中に存在しないと 考えても差し支えない。このことは，溶融 $\mathrm{A} 1$ 中に浸漬した 鋼の表面に特いては $\mathrm{FeAl}_{3}, \mathrm{Fe}_{2} \mathrm{Al}_{5}$ 抌よび $(\alpha \mathrm{Fe})$ 相の成長が

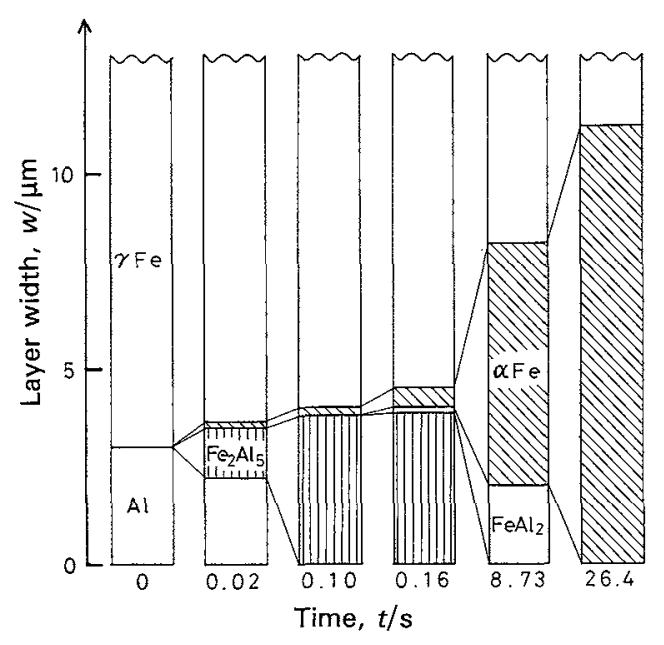

Fig. 6 Appearance and disappearance of phases (Al), $\mathrm{Fe}_{2} \mathrm{Al}_{5}$ and $\mathrm{FeAl}_{2}$, and layer growth of phase $(\alpha \mathrm{Fe})$ in the $\mathrm{Al}$ film of $3.0 \mu \mathrm{m}$ thickness $/ F e$ bulk diffusion couple annealed at $1273 \mathrm{~K}$.
観察されたという報告(25) とは，拡散温度が異なるものの， 搪散領域中に $\mathrm{FeAl}_{3}$ 相が出現しないといら点に関しては勿 論のこと， $\mathrm{FeAl}_{2}$ 相が出現するという点に関しても，異なる ことになる。これは，表面に打ける境界条件の差，すなわ ら，溶融 $\mathrm{A} 1$ 中に浸漬した鋼の場合のよらに常に表面から $\mathrm{Al}$ が供給される条件と，本計算例のように鋼表面において 物質の出入りがない条件との差によって生じるものと考光ら

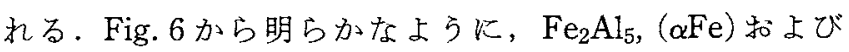
$\mathrm{FeAl}_{2}$ 相は，それぞれ拡散時間0.01, 0.02 抢よび $0.16 \mathrm{~s}$ に出 現し，なた溶融 $\mathrm{Al}, \mathrm{Fe}_{2} \mathrm{Al}_{5}$ および $\mathrm{FeAl}_{2}$ 相の順に消失して いく.

次に，Fig. 6 の最終時間 $26.4 \mathrm{~s}$ からら $3.6 \mathrm{ks}$ での $(\alpha \mathrm{Fe})$ 相 の層幅と表面組成の時間依存性をFig. 7 に示す。図から， 表面 $\mathrm{Al}$ 濃度は比較的短時間の間に急激に減少し，層幅はそ の増加速度を減少さ孙ながら徐々に増加していくことがわか る.な执既に述べたようにこの場合，パラメータ $\omega_{2,0}$ が 著しく大きい值であるため $(\gamma \mathrm{Fe})$ 相の層内においては濃度変 化が認められない。

計算結果の信頼性を確かめるために，スパッタリング装置 を用いて，機械構造用炭素鋼 S10C の鏡面研磨表面上に厚さ $2.1 \mu \mathrm{m}$ の Al 薄膜を形成した後, この試料を真空下で 1273 $\mathrm{K}$ で $3.6 \mathrm{ks}$ 間加熱した.な拝, S10C の化学組成は分析の結 果, C: 0.13 , Si : $0.22, \mathrm{Mn}: 0.42, \mathrm{P}: 0.19, \mathrm{~S}: 0.18$ mass\%で 西った。一方, 上記の実験結果と対応するために $\mathrm{Al}$ 薄膜の 厚さを $2.1 \mu \mathrm{m}$ にとり計算すると， $(\alpha \mathrm{Fe})$ 相の層幅は58.6

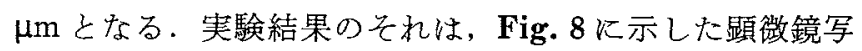

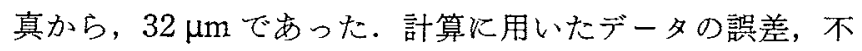
確実性などを考慮すると，雨者はかなりの一致性を示するの と考光てよい。

数值計算結果の精度を次の方法で確かめた。すなわら, 最 終的に得られた $\mathrm{Al}$ 濃度推移曲線を表面からの距離に関して

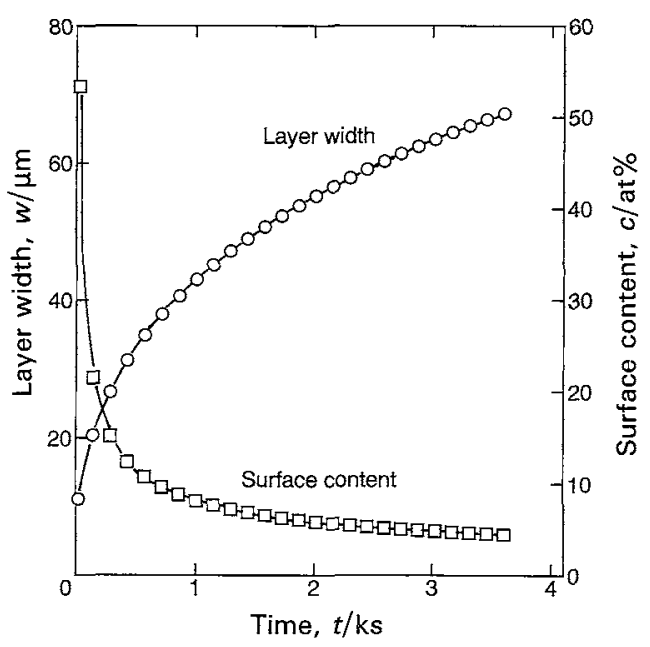

Fig. 7 Time dependence of width and surface Al content of phase $(\alpha \mathrm{Fe})$ formed in the Al film of $3.0 \mu \mathrm{m}$ thickness/Fe bulk diffusion couple annealed at $1273 \mathrm{~K}$. 


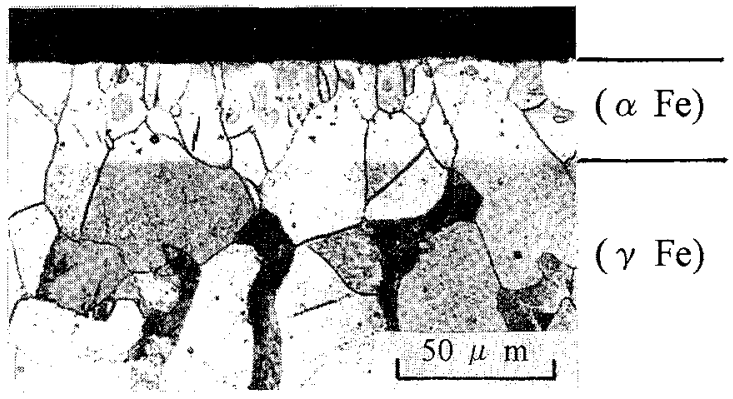

Fig. 8 Optical micrograph showing the Al-diffused layer formed on low carbon steel. Al thickness: $2.1 \mu \mathrm{m}$, Temp.: $1273 \mathrm{~K}$, Time: $3.6 \mathrm{ks}$.

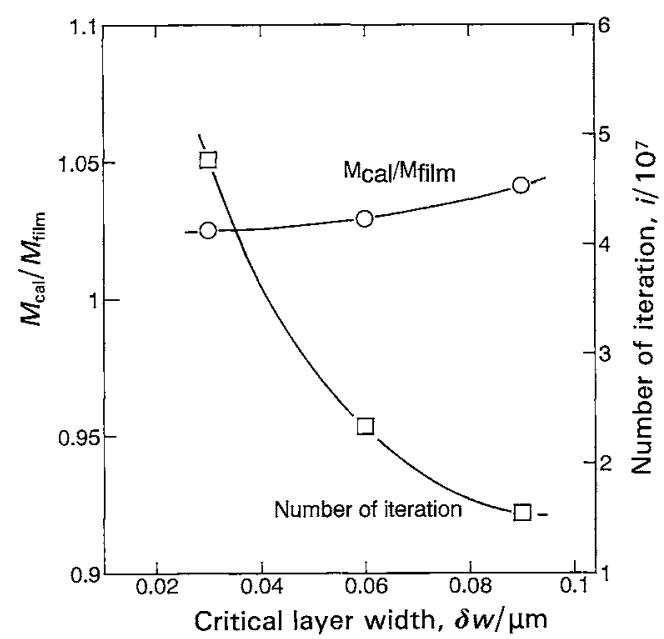

Fig. 9 Dependence of the ratio of $M_{\text {cal }}$ to $M_{\text {film }}$ and number of iterations upon critical layer width $\delta W$ for the Al film of $3.0 \mu \mathrm{m}$ thickness $/ \mathrm{Fe}$ bulk diffusion couple at $1273 \mathrm{~K}$ for $3.6 \mathrm{ks}$. The quantities $M_{\text {cal }}$ and $M_{\text {fim }}$ mean numbers of moles of Al per unit area of surface corresponding to the concentration profile calculated and the thickness of $\mathrm{Al}$ thin film, respectively.

数値積分すると，単位表面積当たりの $\mathrm{A} 1$ モル数 $M_{\mathrm{cal}}$ が得ら れる. 一方，均一化桩散処理前の $\mathrm{Al}$ 薄膜厚さから，単位表 面積当たりの $\mathrm{Al}$ モル数 $M_{\mathrm{film}}$ が得られる. $M_{\mathrm{cal}} / M_{\mathrm{film}}$ 比乱よ び反復計算回数の臨界層幅 $\delta W_{\mathrm{j}}(\mathrm{i})$ への依存性を Fig. 9 飞示 す。たたし，Al 薄膜厚さは $3 \mu \mathrm{m}$ ，距離分割数は 15 とした。 図から明らかなよらに，臨界層幅の増加とともに反復計算回 数 $i$ は急激に減少し，一方， $M_{\mathrm{cal}} / M_{\mathrm{film}}$ 比は徐々に増加して いくが，臨界層幅を均一化拡散処理前のめっき厚さの $1 \%$ に とると，十分な精度が得られることがわかる．ただし，新相 が出現する場合には $R \cdot \delta W$ に相当するモル数の増加, 既存 相が消失する場合には $\delta W に$ 相当するモル数の娍少が認め られるので, 新相の出現特よび既存相の消失が認められない 場合にはその分たり計算精度がよくなる。

\section{3. 薄膜/薄膜拡散対}

薄膜/薄膜桩散対の例として Al-Ni 系を取り上げた．計算
Table 3 Phase boundary compositions ${ }^{(17)} N$ and interdiffusion coefficients $\tilde{D}$, and obtained parameters $\omega$ for the Boltzmann type of infinite couple in the $(\mathrm{Al})-\mathrm{Al}_{3} \mathrm{Ni}_{2}-(\mathrm{Ni})$ system at $773 \mathrm{~K}$. These values were used for calculating Figs. 10 and 11.

\begin{tabular}{l|cc|c|c|c}
\hline \hline Phase (j) & \multicolumn{2}{|c|}{$\begin{array}{c}N_{\mathrm{j}, 0} \\
\left(\text { at\% } \% N_{\mathrm{i}, \mathrm{m}}\right.\end{array}$} & $\begin{array}{c}\tilde{D}_{\mathrm{j}} \\
\left(\mathrm{m}^{2} / \mathrm{s}\right)\end{array}$ & $\omega_{\mathrm{j}, 0}$ & $\omega_{\mathrm{j}, \mathrm{m}}$ \\
\hline$(\mathrm{Al}) \quad(1)$ & 100.0 & 99.99 & $1.05 \times 10^{-16(26)}$ & - & -1.861 \\
$\mathrm{Al}_{3} \mathrm{Ni}(2)$ & 75.1 & 74.9 & $1.36 \times 10^{-16(27)}$ & - & - \\
$\mathrm{Al}_{3} \mathrm{Ni}_{2}(3)$ & 63.1 & 58.7 & $7.73 \times 10^{-15(18)}$ & -0.2169 & 0.0919 \\
$\mathrm{AlNi}(4)$ & 55.2 & 41.0 & $4.42 \times 10^{-19(18)}$ & - & - \\
$\mathrm{AlNi}_{3}(5)$ & 26.8 & 25.1 & $2.35 \times 10^{-17(18)}$ & - & - \\
$(\mathrm{Ni})(6)$ & 8.2 & 0.0 & $5.01 \times 10^{-22(28)}$ & 360.9 & - \\
\hline
\end{tabular}

そ用いた各相の相互拡散係数および相境界組成を Table 3 に示す。な括，Al-Ni系平衡状熊図 ${ }^{(17)}$ に打いては $\mathrm{A}_{3} \mathrm{Ni}$ 相 は線化合物であるが，ここでは 0.2 at\%の組成幅を持つ金属 間化合物であると考えた。 また，同平衡状態図に従うと， $973 \mathrm{~K}$ 以下の温度領域に颃いて $\mathrm{Al}_{3} \mathrm{Ni}_{5}$ 相が存在する。しか し，应散領域に拈ける $\mathrm{Al}_{3} \mathrm{Ni}_{5}$ 相の出現に関しては，これま での Al-Ni 系に関する拡散研究(18)(27)(29)(30)のいずれに扣い

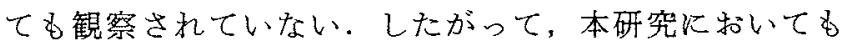
$\mathrm{Al}_{3} \mathrm{Ni}_{5}$ 相は拡散領域に特いて出現しないものと考えた。

Table 3 Kは，表中の值を用いて計算した，Botzmann 型 無限应散対に関するパラメータ $\omega$ も示されている。計算に おいては，III.2で述べたよ5に，均一化抬散の初期段階で 極めて薄い㬝幅を持つ中間相が存在すると，時間刻み幅が小 さな值となり，計算時間が極めて長時間となる。あらかしめ 行った計算の結果(1), 中間相の中で, $\mathrm{Al}_{3} \mathrm{Ni}_{2}$ 相のみが $(\mathrm{Al}$ 薄 膜 $+\mathrm{Ni}$ 薄膜) 厚さの $1 \%$ 以上の層幅を持つことが明らかにな った。そこで， $\mathrm{Al}_{3} \mathrm{Ni}_{2}$ 相のみが初期段階から中間相として 拡散対に存在すると考光た。

拡散条件は $\mathrm{Al}$ 薄膜の厚さ: $0.15 \mu \mathrm{m}, \mathrm{Ni}$ 薄膜の厚さ： $0.37 \mu \mathrm{m}$ ，均一化拡散温度: $723 \mathrm{~K}$ およ゙拡散時間 : $1800 \mathrm{~s}$ を考它た。数值計算て括いては $\delta W=0.005 \mu \mathrm{m}, \Delta c_{-}=$ 0.0001 at $\%, \Delta c_{+}=0.01$ at\%およ゙ $\delta t=0.01 \mathrm{~s}$ とした.

数値計算結果に基づくと, $21 \mathrm{~s}$ 後に( $\mathrm{Al})$ 相が消失すると ともに $\mathrm{Al}_{3} \mathrm{Ni}_{2}$ 相が表面相となり， $\mathrm{Al}_{3} \mathrm{Ni}$ 相は拡散対に出現 することなく，推移する。亦た，表面 $\mathrm{Al}$ 濃度も急激に減少 乙, $38 \mathrm{~s}$ 後飞 $\mathrm{Al}_{3} \mathrm{Ni}_{2}$ 相の表面組成は境界組成 $\mathrm{Al}_{3} \mathrm{Ni}_{2} /$ $\left(\mathrm{Al}_{3} \mathrm{Ni}_{2}+\mathrm{AlNi}\right)$ である 58.70 at\% $\mathrm{Al}$ にをで減少し，ての 後, $\mathrm{Al}_{3} \mathrm{Ni}_{2}$ 相は線化合物のように 58.70 at\% $\mathrm{Al}$ の組成を保 ちながらその層幅を娍少させていく。

均一化拡散時間 $1800 \mathrm{~s}$ K打汁る Al 濃度推移曲線を Fig. 10 K示す。この場合において子既に述べた $(\gamma \mathrm{Fe})$ 相と同様, パラメータ $\omega_{3,0}$ が非常に大きい值であるため，(Ni)相に関 しては濃度変化がなく，Al 濃度は0である。図に和いて明 らかなように， $\mathrm{Al}_{3} \mathrm{Ni}_{2}$ 相と $(\mathrm{Ni})$ 相の各層内に打祳度は 一定であり， $\mathrm{AlNi}$ 相と $\mathrm{AlNi}_{3}$ 相の層内に特计る濃度のみが 距離とともに変化する。一方, 本采関しては, Colgan と Mayer $^{(30)}$ が上記厚さの薄膜/薄膜桩散対に関して上記条件で 


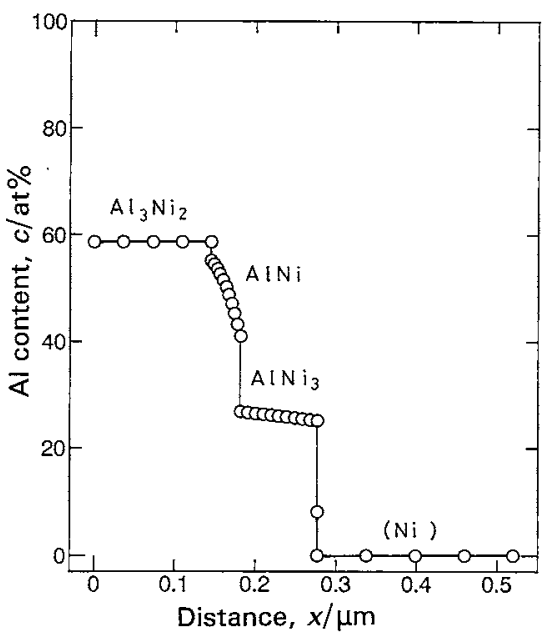

Fig. $10 \mathrm{Al}$ content profile calculated using the values in $\mathrm{Ta}$ ble 3 for the diffusion couple of $0.15 \mu \mathrm{m} \mathrm{Al} / 0.37 \mu \mathrm{m} \mathrm{Ni}$ annealed at $773 \mathrm{~K}$ for $1.8 \mathrm{ks}$.

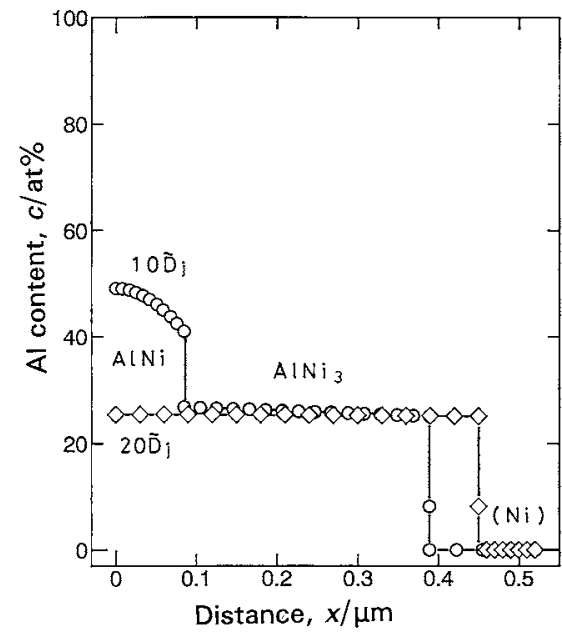

Fig. $11 \mathrm{Al}$ content profiles calculated using the interdiffusion coefficients ten and twenty times those in Table 3 for the diffusion couple of $0.15 \mu \mathrm{m} \mathrm{Al} / 0.37 \mu \mathrm{m} \mathrm{Ni}$ annealed at $773 \mathrm{~K}$ for $1.8 \mathrm{ks}$.

拡散処理を行って，拡散対は $\mathrm{AlNi}_{3}$ と $(\mathrm{Ni})$ 相からなること を報告している。

そこで, Table 3 の相互拡散保数を一律に大きくした場 合，濃度一距離曲線がどのように変わるかる調べてみた。そ れらの結果をFig. 11 亿示寸. 図に轮いて, Table 3 の10倍 の值を持つ相互拡散俰数の場合, AlNi 相は拡散対红残存し, 20 倍の值では AlNi 相が消失し，拡散対は偉かに濃度勾配を 示す $\mathrm{AlNi}_{3}$ と $(\mathrm{Ni})$ 相からのみ成ることを示している。ささら に，図には示していないが，相互拡散係数が100倍の值にな ると, $\mathrm{AlNi}_{3}$ 相内の濃度は全く一様で等しい值となり，相互 拡散係数の值をさらに大きくしていってもこの状沉は変わら ないすなわち，この状況は桩散対が最終的な平衡状態澾
したことを示している。

数值計算結果に基づくと, $\mathrm{Al}_{3} \mathrm{Ni}$ 相は拡散領域沉出現して いないこと（Al) 相は拡散初期に执いて消失していること ならびル $(\mathrm{Ni})$ 相の相互拡散係数は著しく小さいことから， これらの相の相互拡散係数の值炕多少の誤差があったとして も，旮れらが計算結果に寄与するところは小さいものと考克 られる。

さらに, $\mathrm{Al}_{3} \mathrm{Ni}_{2}$ 相の相互拡散係数は, 実験データ(18)を了 レニウス・プロットし，それらの内挿から求めたものであ り，大きな誤差を含む值であるとは考克難い，一方，AlNi 相および $\mathrm{AlNi}_{3}$ 相の相互拡散倸数は, 高温で求められた相互 拡散係数をアレンウス・プロットし，得られた直線を $723 \mathrm{~K}$ 飞外择して求めた值である。拡散係数のアレニゥス・プロッ 卜は注とんどの場合直線となるが，多くの金属では低い温度 領域沈なる，アレニウス・プロットル上向きの曲がりが， 特にbcc 金属で㥩しい曲がりが，見いだされている(31)(32)． したがって，高温領域での測定值からアレニウス・プロット を利用して推定した，Table 3 の $\mathrm{AlNi}$ 相和よび $\mathrm{AlNi}_{3}$ 相の

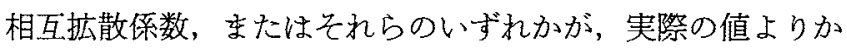
なり小さい値であると考觉られる。

一方, Fig. 10 亿执いて $\mathrm{Al}_{3} \mathrm{Ni}_{2}$ 相の濃度勾配が極めて平坦 であること，逆に $\mathrm{AlNi}$ 相の濃度勾配は著しく急峻であるこ とを考兄ると，拡散対からの $\mathrm{Al}_{3} \mathrm{Ni}_{2}$ 相の消失は，式(7)か らわかるように AlNi 相の相互拡散保数化依存するところが 大きいと考允られる. AlNi 相の相互拡散係数は著しく組成 に依存する。すなわち，汪济 $48 \mathrm{at} \% \mathrm{Al}$ で最小を示し， $\mathrm{Al}_{3} \mathrm{Ni}_{2}$ 相側および $\mathrm{AlNi}_{3}$ 相側の境界組成でそれぞれ 3 桁括 よび 2 桁程度大きい值を示す(28). 既に述べたように, 本数 値計算沃打いては相互拡散係数が組成依存寸る場合，その平 均的相互拉散係数(1) として

$$
\tilde{D}_{\mathrm{j}}=\frac{\int_{C_{\mathrm{j}, \mathrm{m}}}^{\mathrm{C}_{\mathrm{j}, 0}} \tilde{D} \mathrm{~d} c}{C_{\mathrm{j}, 0}-C_{\mathrm{j}, \mathrm{m}}}
$$

によって表される值を用いた。しかし，本拡散対に招讨る AlNi 相の上弓相互拡散係数が著しく強い組成依存性を示 す場合には，上式で表される平均的相互拡散係数でるってそ の相の相互拡散係数を代表させることは困難であるかも知れ ない，今後，現実の拡散過程をより忠実反映する数值計算 結果を得るためには，もちろん正確な入力データを用いるこ とが必要であるが，そ礼とともに，相互拡散係数の組成依存 性を考虑することも是非必要のよう火考えられる。

\section{N. 結言}

$\eta \equiv \mathrm{x} /\left(2 t^{1 / 2}\right)$ が成立する Boltzmann 型拡散関する数值解 析解(1)(2) 加ら求めた濃度推移曲線を初期曲線とし, Murray および Landis の可変格子(15)を用いて，新相の出現および既 存相の消失を伴い，濃度の均一化に向かって進行する 2 元 系多相拡散をシミュレートする数值計算法を明らかとした。 
なお，拡散対の型としては浸透処理後均一化抾散処理を行う 半無限型拡散対, 有限/半無限拡散対乱よび有限/有限拡散対 を対象とし，それぞれの例として Al-Ni系，Al-Fe系および Al-Ni 系を取り上げた。

数值計算プログラムの作成に乱いては，さまざまな 2 元 系合金に適用可能とするために，さらに計算時間を短縮する ために以下の工夫を行った。すなわら

（1）均一化拡散処理の初期段階に蛙いては，ある臨界層幅 $\delta W$ 以下の中間層は拉散対存在しないものとみなす。

（2）初期段階において出現しない相に関しては，計算の過 程に扎いてそれらの相がある臨界值 $R \cdot \delta W$ 以上の層幅を持 つか否かをチェックし，R・ $\delta W$ 以上の条件を満足する相の 中で最も大きな層幅を持つ相のみが，新た桩散対に出現す るものとみなす。

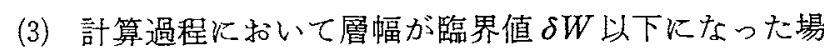
合，その相は拉散対から消失したものと双なす。

(4) 上記(2)扣よび(3)のチェックは，各時間行ごとではな

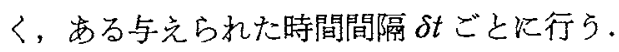

上記の活かに，プログラム作成に物いては特殊条件に対し て以下の対策を講じた。

(5) 相 1 または相 nの組成幅がある臨界值 $\delta c$ 以下の場 合，またはとれらの相のいずれかに関して $\omega_{1, \mathrm{~m}}<-\Omega_{\max }$, または $\omega_{\mathrm{n}, 0}>\Omega_{\max }$ が満足される場合，その端末相内に扣い ては抎散による濃度変化はないものとみなす。

数値計算結果と実験結果との比較扣よび単位断面積当たり のモル数の検討から，本研究で確立した数値計算方法は，拡 散領域内での新相の出現および敢存相の消隇を含む 2 元系 多相桩散現象に関して，妥当な結果を与え，また十分な精度 を有するものである。

\section{文献}

(1) 过 新次：日本金属学会誌，41(1977), 670 .

(2) S. Tsuji: Metall. Trans. A, 25A (1994), 753.

(3) A. J. Hickl and R. W. Heckel: Metall. Trans. A, 6A (1975), 431.
（4）太刀川恭治, 福田佐登志 : 日本金属学会誌, 29(1965), 1125.

(5) K. Tachikawa and Y. Isawa: Appl. Phys. Letters, 16(1970), 230.

（6）伊藤太一郎, 菲村紀文: 日本金属学会会報, 28(1989), 785 .

(7) 平柖夫 : 応用物理, $51(1982), 143$.

（8）和気亮介：表面技術，42(1991)，868.

（9）吉村昭三, 尾崎治一, 絔舟秀美, 水本省三, 園田 司 : 表面 技術, 44(1993)，176.

(10) R. A. Tanzilli and R. W. Heckel: Trans. Met. Soc. AIME, 242(1968), 2313.

(11) R. D. Lanam and R. W. Heckel: Metall. Trans., 2(1971), 2255.

(12) W. C. Johnson and R. W. Heckel: Metall. Trans. A, 12A (1981), 1693.

（13）下崎敏唯, 岩松良徳, 大西正已：日本金属学会誌，52(1988), 639.

（14）下㟝敏唯，岩松良徳，大西正已：日本金属学会誌，57(1993), 729.

(15) D. Murray and F. Landis: Trans. ASME Ser. D, 81(1959), 106.

(16) G. D. Smith 著, 藤川洋一郎訳: 電算機に上る微分方程式の解 法, サイエンスライブラリ情報電算機 $=3$, サイエンス社, (1979), 10.

(17) M. F. Singleton, J. L. Murray and P. Nash: Binary Alloy Phase Diagrams vol. 1, Ed. by T. B. Massalski, ASM, Ohio, (1986), 181.

(18) M. M. P. Janssen and G. D. Rieck: Trans. AIME, 239(1967), 1372.

(19) U. R. Kattner: Binary Alloy Phase Diagrams vol. 1, Ed. by T. B. Massalski, ASM, Ohio, (1986), 147.

(20) A. K. Roy and R. P. Chhabra: Metall. Trans., 19A (1988), 273.

(21) P. K. Bamola and L. L. Seigle: Metall. Trans., 20A(1989), 2561.

(22) V. E. Neverov and V. N. Pimenov: Fizik. N. Chimiya Obrabotke Materialov, 5 (1980), 104.

（23）平野賢一，菱沼章道：日本金属学会誌，32(1968)，516.

(24) C. B. Birchenall and R. Mehl: Trans. AIME, 188(1950), 144.

（25）上田俶完，新家光雄：日本金属学会誌，42(1978)，543.

(26) K. Hirano, R. P. Agarmala and M. Cohen: Acta Met., $10(1962), 857$.

(27) L. S. Castleman and L. L. Seigle: Trans. AIME, 212(1958), 589.

(28) R. Shankar and L. L. Seigle: Metall. Trans. A, 9 (1978), 1467.

(29) S. Storchheim, J. L. Zambrow and H. H. Hausner: Trans. AIME, 200(1954), 269.

(30) E. G. Colgan and J. W. Mayer: in Thin films-Interfaces and Phenomena, ed. by R. J. Nelmanich, P. S. Ho and S. S. lau, Materials Research Society Symposium Proceedings, Material Research Society, (1986), vol. 54, p. 121.

(31) E. G. Colgan and J. W. Mayer: Mat. Res. Soc. Symp. Proc., $\mathbf{5 4}(1986), 121$

（32）飯島嘉明：日本金属学会会報，21(1982)，705 